\title{
The antibacterial and antifungal activities of gatifloxacin and its metal complexes
}

\author{
${ }^{1}$ Muhammad Inam-Ul-Haq, ${ }^{1}$ Tehseen Ahmed $*,{ }^{2}$ Fatima Ahmed \\ ${ }^{1}$ Department of Chemistry, University of Karachi, Karachi, Pakistan \\ ${ }^{2}$ The First Faculty of Medicine of Charles University, Prague, Czech Republic \\ *Corresponding Author's Email: tahmed@uok.edu.pk
}

\begin{abstract}
The present article reports the biological activity of gatifloxacin separately and simultaneously as a ligand and in form of the metal complex in vitro. Gatifloxacin is a member of the fluoroquinolone group and members of this group form metal complexes due to their high tendency to bind with metal ions. The metal complexes of the gatifloxacin synthesized with several metals like $\mathrm{Mg}$ (II), $\mathrm{Al}$ (III), $\mathrm{Ca}(\mathrm{II}), \mathrm{Cr}(\mathrm{III}), \mathrm{Mn}(\mathrm{II}), \mathrm{Fe}(\mathrm{III}), \mathrm{Co}(\mathrm{II}), \mathrm{Ni}(\mathrm{II}), \mathrm{Cu}(\mathrm{II})$ and $\mathrm{Zn}$ (II) in a ratio of 1:2 molar ratios of metal and ligand (M: L). It was observed that the fluorine group at position 6 and the piperazine group at position 7 greatly enhanced the spectrum of activity. Antibacterial and antifungal activities of gatifloxacin and its metal complexes were determined by the agar diffusion method. The biological activity (antibacterial and antifungal) was tested against Escherichia coli, Staphylococcus aureus, Salmonella typhi, Pseudomonas aeruginosa, Campylobacter jejuni, Neisseria gonorrhoeae, Corynebacterium diphtherire, Clostridium perfringens, Pasteurella multocida, and fungus Aspergillus niger and Fusarium oxysporum. It was concluded that the as-prepared gatifloxacin metal complexes with divalent and trivalent metal ions showed enhanced antibacterial activities while no antifungal activities in comparison to gatifloxacin were observed.
\end{abstract}

Keywords: Gatifloxacin; metals; antibacterial; antifungal activities

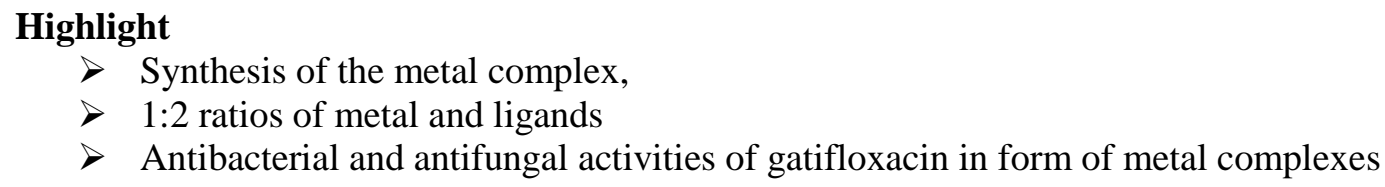

\section{Introduction}

Gatifloxacin is a synthetic white crystalline chemotherapeutic agent, has a broad-spectrum antimicrobial activity and a unique mechanism of action. It is used as a racemate, with no net optical rotation. Gatifloxacin is a potent antibacterial agent belonging to the fluoroquinolone group. The antibacterial action of gatifloxacin results in inhibition of DNA gyrase and topoisomerase IV. DNA gyrase is an essential enzyme involved in the replication, transcription, and repair of bacterial DNA. Topoisomerase IV is an enzyme known to play a key role in the partitioning of chromosomal DNA during bacterial cell division. The antibacterial activities of $\mathrm{R}$ and $\mathrm{S}$ enantiomers are virtually identical (Al-Abdullah, 2012). The maximum aqueous solubility $(40-60 \mathrm{mg} / \mathrm{mL})$ occurs at a $\mathrm{pH}$ range of 2-5 (Repchinsky, 2003). Gatifloxacin has a piperazino group at the $\mathrm{C} 7$ position. The methyl substituent on the piperazine ring enhances the Gram-positive activity, extends the half-life, and supports metabolic stability. It has a cyclopropyl group at the $\mathrm{N} 1$ position which enhances Gram-negative activity and contributes some Gram-positive activity. Gatifloxacin does not have a 2,4-difluorophenyl group at the N1 position which results in the lack of hepatic and hematologic toxicities associated with other fluoroquinolones (Blum et al., 1994; Lipsky, \& Baker, 1999; Zhao et al., 1997). Due to the lack of halide at the C8 position, the photo-toxicity is reduced. The presence of the methoxy group at the C8 position enhances activity against DNA gyrase and topoisomerase IV. This substituent can reduce the potential for the development of bacterial resistance (Domagala, 1994; Park-Wyllie et al., 2006; Lipsky, \& Baker, 1999; Drlica, 1999; Fukuda et al., 2001; Ito et al., 1995). Metal ions are known to affect the action of many drugs. The efficacy of the drugs on coordination with metal is enhanced in many cases (Farrell, 2003).

Metal ions play a vital role in a vast number of widely dissimilar biological processes and depending on their concentration, they might have either contributed towards the health of the organism or cause toxicity (Sabale et al., 2012; Sadler, \& Guo, 1998). Several metals chelate are known to possess antibacterial, ant fungicidal, antiviral, and anti-cancerous activity. In numerous cases, the metal chelates are more antimicrobial than the chelating agents themselves (Tarushi et al., 2013). The coordination chemistry of fluoroquinolone drugs with metal ions is of considerable interest associated with 
biological and pharmaceutical significant metal. There have been several reports in the literature about the synthesis and crystal structure of metal complexes with different quinolone and fluoroquinolones group antibiotics.

The current research reports the synthesis of complex and their characterization using advanced technologies. The biological activities of synthesized complexes were measured in vitro study using the agar diffusion method.

\section{Materials and methods}

Gatifloxacin was obtained from Sigma-Aldrich. All reagents used were analytical and HPLC grade. Bi-distilled water was obtained by passing deionized water through a Millipore water system. This bi-distilled and deionized water was used in the preparation of all solutions of reagents and buffers. Gatifloxacin is a synthetic broad-spectrum quinolone antibacterial agent for ophthalmic uses. Chemically gatifloxacin is ( \pm )-1-cyclopropyl-6-fluoro-1,4-dihydro-8-methoxy7-(3methylpiperazino)-4-oxo-3-quinolinecarboxylic acid sesquihydrate (Gayakwad et al., 2018). The empirical formula of gatifloxacin is $\mathrm{C}_{19} \mathrm{H}_{22} \mathrm{FN}_{3} \mathrm{O}_{4} \bullet 1.5 \mathrm{H}_{2} \mathrm{O}$ and its molecular weight is $402.42 \mathrm{~g} \mathrm{~mol}^{-1}$ while the structural formula is shown in Figure 1.

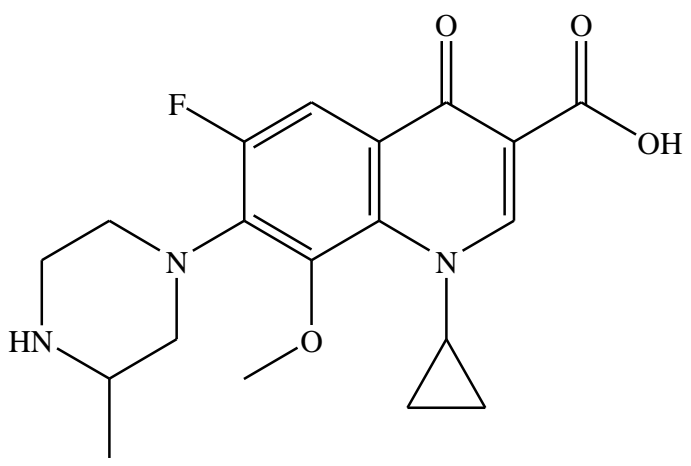

Fig. 1. Chemical structure of gatifloxacin

\subsection{Synthesis of the complexes}

The metal complexes of gatifloxacin were prepared by using $50 \mathrm{~mL}$ of $1 \mathrm{mM}$ hot methanolic solution of gatifloxacin with simultaneous addition of $50 \mathrm{~mL}$ of $0.5 \mathrm{mM}$ solution of metal chloride $\left(\mathrm{MgCl}_{2} \cdot 6 \mathrm{H}_{2} \mathrm{O}, \mathrm{AlCl}_{3} \cdot 6 \mathrm{H}_{2} \mathrm{O}, \mathrm{CaCl}_{2} \cdot 2 \mathrm{H}_{2} \mathrm{O}\right.$, $\mathrm{CrCl}_{3} \bullet 6 \mathrm{H}_{2} \mathrm{O}, \mathrm{MnCl}_{2} \bullet 4 \mathrm{H}_{2} \mathrm{O}, \mathrm{FeCl}_{3} \bullet 6 \mathrm{H}_{2} \mathrm{O}, \mathrm{CoCl}_{2} \bullet 6 \mathrm{H}_{2} \mathrm{O}, \mathrm{NiCl}_{2} \bullet 6 \mathrm{H}_{2} \mathrm{O}, \mathrm{CuCl}_{2} \bullet 2 \mathrm{H}_{2} \mathrm{O}$, and $\mathrm{ZnCl}$ ) in double-distilled water and mixing with a magnetic stirrer (chloride form of all metals chosen for complex preparation). In this preparation, a 1:2 molar ratio of metal and ligand (M: L) was used. The reaction mixture was continuously heated on a water bath for 4-4.5 h at 50 ${ }^{\circ} \mathrm{C}$, then the mixture was filtered and the solution concentrated under reduced pressure. The complexes were characterized by their elemental analysis, atomic absorption, infrared and UV-visible spectroscopy. Although gatifloxacin metal complexes are crystalline but not suitable for X-ray diffraction analysis. Characterization of metal complexes was conducted by physicochemical methods which are as follows while color of complexes monitored by visual observation

\subsection{Solubility test}

The solubility of the metal complexes was tested using a various polar solvent like methanol, DMF, and DMSO and nonpolar solvents like benzene, cyclohexane, ether, and carbon tetrachloride

\subsection{Melting point}

The melting point of the metal complexes was recorded on a Gallenkamp melting point apparatus.

\subsection{Analysis of the synthesized complexes}

The IR spectra of gatifloxacin and their metal complexes were recorded on a Shimadzu FTIR Prestige -21 spectrophotometer by using $\mathrm{KBr}$ pellets in the $4000-400 \mathrm{~cm}^{-1}$ range. The elemental analysis was carried out with a standard micro method using Carlo-Erba 1106. Perkin-Elmer Analyst 700 atomic absorption spectrometers used for atomic absorption studies. The 
UV-visible spectra were recorded on Beckman Coulter DU 730 and Shimadzu 1700 connected to computer loaded UVProbe version 2.3 software. HPLC studies were carried out on Lab Alliance HPLC connected with NavChrom software and the Shimadzu Technologies LC 20 series LC system was used for method development and validation studies. The chromatograms were analyzed with Shimadzu lab solution HPLC software.

\subsection{Biological Activities}

In vitro antibacterial and antifungal activities of gatifloxacin and its metal complexes were determined by agar diffusion method (Perilla, 2003; FDA, 2015) against different bacterial strains such as Escherichia coli, Staphylococcus aureus, Salmonella typhi, Pseudomonas aeruginosa, Campylobacter jejuni, Neisseria gonorrhoeae, Corynebacterium diphtherire, Clostridium perfringens, Pasteurella multocida, and fungus Aspergillus niger and Fusarium oxysporum. For this purpose, different concentrations $(5,10,20$, and $40 \mu \mathrm{g} / \mathrm{mL})$ of antibacterial discs $(6 \mathrm{~mm})$ were prepared and dried at $37{ }^{\circ} \mathrm{C}$. The nutrient agar medium (Oxoid) was used for antibacterial and for antifungal studies, the sabouraud dextrose agar medium (Merck) was prepared, then cooled to $40{ }^{\circ} \mathrm{C}$ and seeded with test microorganisms. These culture plates were then incubated at $37{ }^{\circ} \mathrm{C}$ for $24 \mathrm{~h}$ for bacteria while seven days at $30{ }^{\circ} \mathrm{C}$ for fungal culture. The activity was determined by measuring the diameter of the inhibition zone (in $\mathrm{mm}$ ). Growth inhibition was calculated regarding the positive control of gatifloxacin. While DMSO paper discs were used as a negative control to assess the positive control (Table 1).

TABLE 1

Antibacterial and antifungal activity of gatifloxacin and Its metal complexes

\begin{tabular}{|c|c|c|c|c|c|c|c|c|c|c|c|}
\hline $\begin{array}{l}\text { Compoun } \\
\text { ds }\end{array}$ & $\begin{array}{l}\text { C. } \\
\text { perfringe } \\
\text { ns }\end{array}$ & $\begin{array}{l}\text { C. } \\
\text { jejuni }\end{array}$ & $\begin{array}{l}\text { C. } \\
\text { diphtheri } \\
\text { ae }\end{array}$ & $\begin{array}{l}E . \\
\text { coil }\end{array}$ & $\begin{array}{l}\text { S. } \\
\text { aureu } \\
\text { S }\end{array}$ & $\begin{array}{l}\text { S. } \\
\text { typi }\end{array}$ & $\begin{array}{l}P . \\
\text { aerugino } \\
\text { sa }\end{array}$ & $\begin{array}{l}P . \\
\text { multoci } \\
d a\end{array}$ & $\begin{array}{l}\text { N. } \\
\text { gonorrhoe } \\
\text { ae }\end{array}$ & $\begin{array}{l}\text { A. } \\
\text { nige } \\
r\end{array}$ & $\begin{array}{l}F . \\
\text { oxysporu } \\
m\end{array}$ \\
\hline & & ++++ & & & ++++ & ++++ & & & & & \\
\hline GTX-Mg & +++++ & + & +++++ & $\begin{array}{l}++++ \\
++++\end{array}$ & + & + & ++++ & +++++ & +++++ & na & na \\
\hline GTX-Ca & +++++ & +++ & +++++ & + & ++++ & +++ & +++++ & +++ & ++++ & na & na \\
\hline GTX-Al & ++++ & +++ & +++ & +++ & +++ & +++ & +++ & +++ & ++++ & na & na \\
\hline GTX-Cr & +++++ & +++ & +++++ & $\begin{array}{l}+++ \\
++++\end{array}$ & ++++ & ++++ & +++ & +++++ & ++++ & na & na \\
\hline GTX-Mn & +++++ & $\begin{array}{l}+++ \\
++++\end{array}$ & +++++ & + & ++++ & +++ & +++++ & +++++ & ++++ & na & na \\
\hline GTX-Fe & +++++ & + & +++++ & ++++ & ++++ & ++++ & ++++ & +++++ & ++++ & na & na \\
\hline GTX-Co & +++++ & ++++ & +++++ & ++++ & ++++ & ++++ & +++++ & +++++ & ++++ & na & na \\
\hline GTX-Ni & +++++ & $\begin{array}{l}++++ \\
+\end{array}$ & +++++ & ++++ & $\begin{array}{l}++++ \\
+\end{array}$ & +++ & ++++ & +++++ & ++++ & na & na \\
\hline GTX-Cu & +++++ & $\begin{array}{l}++++ \\
+\end{array}$ & +++++ & ++++ & ++++ & +++ & +++ & +++++ & ++++ & na & na \\
\hline GTX-Zn & +++++ & ++++ & ++++ & ++++ & $\begin{array}{l}++++ \\
+\end{array}$ & ++++ & ++++ & +++++ & ++++ & na & na \\
\hline GTX & ++++ & ++++ & ++++ & ++++ & ++++ & ++++ & ++++ & ++++ & ++++ & na & na \\
\hline
\end{tabular}


Abbreviation: C. perfringens Clostridium perfringens, C. jejuni Campylobacter jejuni, C. diphtheriae Corynebacterium diphtheriae, E. coli Escherichia coli, $\quad$ S. aureus Staphylococcus aureus, S. tyhpi Salmonella typhi, P. aeruginosa Pseudomonas aeruginosa, P. multocida Pasteurella multocida, N. gonorrhoeae Neisseria gonorrhoeae, A. niger Aspergillus niger and F. oxysporum Fusarium oxysporum

$$
\begin{array}{ll}
\text { Excellent activity } & =+++++ \\
\text { Good activity } & =++++ \\
\text { Moderate activity } & =+++ \\
\text { Significant activity } & =++ \\
\text { Negligible activity } & =+ \\
\text { No activity } & =
\end{array}
$$

\section{Results and Discussion}

\subsection{Stoichiometry of Gatifloxacin-Metal Complexes}

Stoichiometry of gatifloxacin-metal complexes was studied by mole ratio and Job's methods. These methods are excellent when $\mathrm{M}$ and $\mathrm{L}$ species have different spectroscopic properties as compared to the complex $M L_{n}$. Initially, $\lambda_{\max }$ was calculated by scanning the spectrum of gatifloxacin-metal complexes at $\mathrm{pH}$ under consideration. During the scanning of the spectrum, it was found that the $\lambda_{\max }$ value of gatifloxacin-metal complexes varied with $\mathrm{pH}$.

\subsection{Synthesis and characterization}

\subsubsection{Physicochemical properties of the Gatifloxacin metal complexes}

The metal complexes were prepared by refluxing in an appropriate amount of metal salts with gatifloxacin in methanol.

\begin{tabular}{|c|c|c|c|c|}
\hline S.No & Compound & Color & M.P. ${ }^{\circ} \mathrm{C}$ & \% Yield \\
\hline 1 & Gatifloxacin & Off White & & \\
\hline & & & 158 & ----- \\
\hline 2 & {$\left[\mathrm{Mg}\left(\mathrm{C}_{19} \mathrm{H}_{22} \mathrm{~N}_{3} \mathrm{O}_{4} \mathrm{~F}\right)_{2}\left(\mathrm{H}_{2} \mathrm{O}\right)_{2}\right] \mathrm{Cl}_{2} 2 \mathrm{H}_{2} \mathrm{O}$} & Off White & 250 & 81 \\
\hline 3 & {$\left[\mathrm{Al}\left(\mathrm{C}_{19} \mathrm{H}_{22} \mathrm{~N}_{3} \mathrm{O}_{4} \mathrm{~F}\right)_{2} \mathrm{ClH}_{2} \mathrm{O}\right] \mathrm{Cl} \_2 \mathrm{H}_{2} \mathrm{O}$} & Off White & 197 & 82 \\
\hline 4 & {$\left[\mathrm{Ca}\left(\mathrm{C}_{19} \mathrm{H}_{22} \mathrm{~N}_{3} \mathrm{O}_{4} \mathrm{~F}\right)_{2}\left(\mathrm{H}_{2} \mathrm{O}\right)_{2}\right] \mathrm{Cl}_{2} 2 \mathrm{H}_{2} \mathrm{O}$} & Off White & 227 & 83 \\
\hline 5 & $\begin{array}{l}{\left[\mathrm{Cr}\left(\mathrm{C}_{19} \mathrm{H}_{22} \mathrm{~N}_{3} \mathrm{O}_{4} \mathrm{~F}\right)_{2} \mathrm{Cl}\left(\mathrm{H}_{2} \mathrm{O}\right)_{2}\right]} \\
\mathrm{Cl}_{2} 2 \mathrm{H}_{2} \mathrm{O}\end{array}$ & Green & 222 & 82 \\
\hline 6 & {$\left[\mathrm{Mn}\left(\mathrm{C}_{19} \mathrm{H}_{22} \mathrm{~N}_{3} \mathrm{O}_{4} \mathrm{~F}\right)_{2}\left(\mathrm{H}_{2} \mathrm{O}\right)_{2}\right]_{-} 6 \mathrm{H}_{2} \mathrm{O}$} & Pale yellow & 221 & 84 \\
\hline 7 & $\begin{array}{l}{\left[\mathrm{Fe}\left(\mathrm{C}_{19} \mathrm{H}_{22} \mathrm{~N}_{3} \mathrm{O}_{4} \mathrm{~F}\right)_{2} \mathrm{Cl}\left(\mathrm{H}_{2} \mathrm{O}\right)_{2}\right]} \\
\mathrm{Cl} \_2 \mathrm{H}_{2} \mathrm{O}\end{array}$ & $\begin{array}{l}\text { Reddish } \\
\text { brown }\end{array}$ & 191 & 87 \\
\hline 8 & {$\left[\mathrm{Co}\left(\mathrm{C}_{19} \mathrm{H}_{22} \mathrm{~N}_{3} \mathrm{O}_{4} \mathrm{~F}\right)_{2}\left(\mathrm{H}_{2} \mathrm{O}\right)_{2}\right]_{4} 4 \mathrm{H}_{2} \mathrm{O}$} & Pink & 193 & 87 \\
\hline
\end{tabular}
Metal complexes were prepared by using the metal salts of chloride ion with the gatifloxacin in molar ratios of metal to the ligand in the ratio 1:2. It was observed that the data of calculated percentages of elemental analysis (CHN) were in good agreement with each other and proved the suggested molecular formulas of the complexes (Table 2 \& Fig. 2).

Table 2

Physicochemical parameters of gatifloxacin and its metal complexes 


\begin{tabular}{lllll}
9 & {$\left[\mathrm{Ni}\left(\mathrm{C}_{19} \mathrm{H}_{22} \mathrm{~N}_{3} \mathrm{O}_{4} \mathrm{~F}\right)_{2}\left(\mathrm{H}_{2} \mathrm{O}\right)_{2}\right] \mathrm{Cl}_{2} 2 \mathrm{H}_{2} \mathrm{O}$} & Light green & 258 & 90 \\
10 & {$\left[\mathrm{Cu}\left(\mathrm{C}_{19} \mathrm{H}_{22} \mathrm{~N}_{3} \mathrm{O}_{4} \mathrm{~F}\right)_{2}\left(\mathrm{H}_{2} \mathrm{O}\right)_{2}\right] \_\mathrm{H}_{2} \mathrm{O}$} & Dirty green & 175 & 87 \\
11 & $\left.\left[\mathrm{Zn}\left(\mathrm{C}_{19} \mathrm{H}_{22} \mathrm{~N}_{3} \mathrm{O}_{4} \mathrm{~F}\right)_{2} \mathrm{H}_{2} \mathrm{O}\right)_{2}\right] \_2 \mathrm{H}_{2} \mathrm{O}$ & Dirty White & 191 & 78 \\
\hline
\end{tabular}

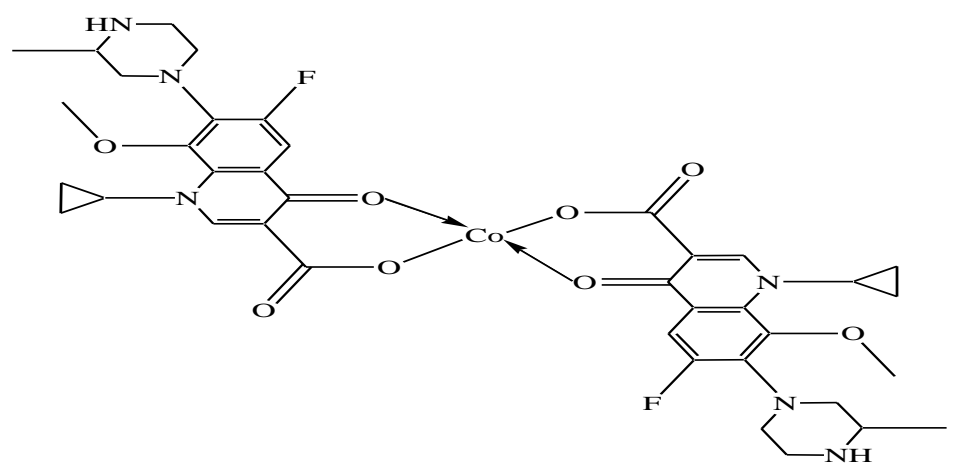

Fig. 2. Proposed structural formula of metal complex

\subsubsection{Solubility and Melting point}

The solubility test of these complexes showed that they were insoluble in benzene, cyclohexane, ether, and carbon tetrachloride while slightly soluble in water while soluble in methanol, DMF, and DMSO. The melting point obtained for each of these complexes is found to be higher than the melting point of the ligand. This shows that there is coordination between the ligand and their metal salts, thereby resulting in complexation (Table 2).

\subsection{Elemental Analysis of the complexes}

Atomic absorption analysis was carried out by direct method to estimate the total metal contents. For this purpose, the reference solutions of different metals having various concentrations were prepared. The absorbance was noted at a specific wavelength of each metal by using the background correction technique (Farrell, 2003). For each metal solution, the graph was plotted between absorbance and concentration. The concentration of the unknown solution was calculated from the absorbance of the unknown solution using standard values. The results obtained from elemental analysis and atomic absorption are shown in Table 3. These results suggest the same formulas of the gatifloxacin metal complexes is $\left[\mathrm{M}(\mathrm{gati})_{2} \bullet \mathrm{nH}_{2} \mathrm{O}\right] \mathrm{Cl}_{2} \bullet \mathrm{nH}_{2} \mathrm{O}$. The most probable structures of the complexes are shown in Fig. 3. The gatifloxacin complexes most probably have six coordinates with two molecules of gatifloxacin chelating metal atom and four other atoms derived from water and chloride ions.

\section{TABLE 3}

Elemental analysis of gatifloxacin and its metal complexes

\begin{tabular}{|c|c|c|c|c|c|}
\hline $\begin{array}{l}\text { S.N } \\
\text { o }\end{array}$ & Compound & $\mathrm{C} \%$ & H\% & N\% & Metal \% \\
\hline 1 & Gatifloxacin & 56.71 & 6.21 & 10.44 & ---------- \\
\hline 2 & $\begin{array}{l}{\left[\mathrm{Mg}\left(\mathrm{C}_{19} \mathrm{H}_{22} \mathrm{~F} \mathrm{~N}_{3} \mathrm{O}_{4}\right)_{2}\left(\mathrm{H}_{2} \mathrm{O}\right)_{2}\right]} \\
\mathrm{Cl}_{2} 2_{2} \mathrm{H}_{2} \mathrm{O}\end{array}$ & $50.02,(49.71)$ & $5.49,(5.66)$ & $9.14,(9.15)$ & $2.72,(2.64)$ \\
\hline 3 & {$\left[\mathrm{Al}\left(\mathrm{C}_{19} \mathrm{H}_{22} \mathrm{FN}_{3} \mathrm{O}_{4}\right)_{2} \mathrm{ClH}_{2} \mathrm{O}\right] \mathrm{Cl} \_2 \mathrm{H}_{2} \mathrm{O}$} & $50.01,(50.55)$ & $5.21,(5.54)$ & $9.10,(9.31)$ & $2.81,(2.99)$ \\
\hline 4 & $\begin{array}{l}{\left[\mathrm{Ca}\left(\mathrm{C}_{19} \mathrm{H}_{22} \mathrm{FN}_{3} \mathrm{O}_{4}\right)_{2}\right.} \\
\mathrm{Cl}_{2} \_2 \mathrm{H}_{2} \mathrm{O}\end{array}$ & $48.52,(48.87)$ & $5.40,(5.57)$ & $9.01,(9.00)$ & $\begin{array}{l}4.32 \\
(4.29)\end{array}$ \\
\hline 5 & $\begin{array}{l}{\left[\mathrm{Cr}\left(\mathrm{C}_{19} \mathrm{H}_{22} \mathrm{FN}_{3} \mathrm{O}_{4}\right)_{2} \mathrm{Cl}\left(\mathrm{H}_{2} \mathrm{O}\right)_{2}\right]} \\
\mathrm{Cl} \_2 \mathrm{H}_{2} \mathrm{O}\end{array}$ & $48.15,(48.25)$ & $5.15,(5.50)$ & $9.01,(8.88)$ & $5.48,(5.50)$ \\
\hline
\end{tabular}




\begin{tabular}{clllll}
\hline 6 & {$\left[\mathrm{Mn}\left(\mathrm{C}_{19} \mathrm{H}_{22} \mathrm{~F} \mathrm{~N}_{3} \mathrm{O}_{4}\right)_{2}\left(\mathrm{H}_{2} \mathrm{O}\right)_{2}\right]_{-} 6 \mathrm{H}_{2} \mathrm{O}$} & $48.00,(48.05)$ & $6.11,(6.32)$ & $8.84,(8.85)$ & $5.74,(5.79)$ \\
7 & {$\left[\mathrm{Fe}\left(\mathrm{C}_{19} \mathrm{H}_{22} \mathrm{~F} \mathrm{~N}_{3} \mathrm{O}_{4}\right)_{2} \mathrm{Cl}\left(\mathrm{H}_{2} \mathrm{O}\right)_{2}\right]$} & $48.65,(48.05)$ & $5.48,(5.48)$ & $8.82,(8.85)$ & $5.84,(5.90)$ \\
& $\mathrm{Cl} 22 \mathrm{H}_{2} \mathrm{O}$ & & & & \\
8 & {$\left[\mathrm{Co}\left(\mathrm{C}_{19} \mathrm{H}_{22} \mathrm{~F} \mathrm{~N}_{3} \mathrm{O}_{4}\right)_{2}\left(\mathrm{H}_{2} \mathrm{O}\right)_{2}\right]_{-} 4 \mathrm{H}_{2} \mathrm{O}$} & $50.02,(49.73)$ & $5.89,(6.10)$ & $9.12,(9.16)$ & $6.41,(6.43)$ \\
9 & {$\left[\mathrm{Ni}\left(\mathrm{C}_{19} \mathrm{H}_{22} \mathrm{~F} \mathrm{~N}_{3} \mathrm{O}_{4}\right)_{2}\left(\mathrm{H}_{2} \mathrm{O}\right)_{2}\right]$} & $48.00,(47.91)$ & $5.28,(5.46)$ & $8.85,(8.82)$ & $6.01,(6.16)$ \\
& $\mathrm{Cl}_{2 \_} 2 \mathrm{H}_{2} \mathrm{O}$ & & & & \\
10 & {$\left[\mathrm{Cu}\left(\mathrm{C}_{19} \mathrm{H}_{22} \mathrm{~F} \mathrm{~N}_{3} \mathrm{O}_{4}\right)_{2}\left(\mathrm{H}_{2} \mathrm{O}\right)_{2}\right]_{-} \mathrm{H}_{2} \mathrm{O}$} & $51.81,(52.56)$ & $5.67,(5.76)$ & $9.56,(9.68)$ & $7.01,(7.32)$ \\
11 & {$\left[\mathrm{Zn}\left(\mathrm{C}_{19} \mathrm{H}_{22} \mathrm{~F} \mathrm{~N}_{3} \mathrm{O}_{4}\right)_{2}\left(\mathrm{H}_{2} \mathrm{O}\right)_{2}\right]_{-} \mathrm{H}_{2} \mathrm{O}$} & $51.23,(51.38)$ & $5.58,(5.85)$ & $9.34,(9.46)$ & $7.35,(7.36)$
\end{tabular}



Fig. 3. Spectrum of gatifloxacin complexes

\subsection{UV-Visible Analysis of the metal complexes}

The characterization of synthesized metal complexes was also conducted by UV-visible spectrophotometry. The spectra of the gatifloxacin and its metal complexes were scanned in the region of $200-800 \mathrm{~nm}$. The spectral analysis of all metal complexes showed absorption maxima around $330 \mathrm{~nm}$ which may be assigned to ligand-metal electron transfer. The absorption spectrum of gatifloxacin showed three absorption peaks at 254, 291 and $310 \mathrm{~nm}$, these peaks could be assigned to $\pi-\pi^{*}$ and $n-\pi^{*}$ transition within the organic ligand (Saravolatz, \& Leggett, 2003). In all gatifloxacin complexes the maximum absorption peaks had relatively high bathochromic shifts, this can be attributed to the reaction of the metal ions with the ketonic oxygen and carboxylic oxygen in the conjugated system of the drug, which directly resulted in the changes of absorption spectra and bathochromic shifts of the maximum absorption peaks. Whereas in the case of gatifloxacin complexes new absorption peaks appeared around $330 \mathrm{~nm}$ and all the other absorption peaks are bathochromic shifted. The shift of $\lambda_{\max }$ to higher values (bathochromic shift) and lower values (hypsochromic shift) for the complexes attributed to the complexation behavior of gatifloxacin towards metal ions (Fig.3 \&4).

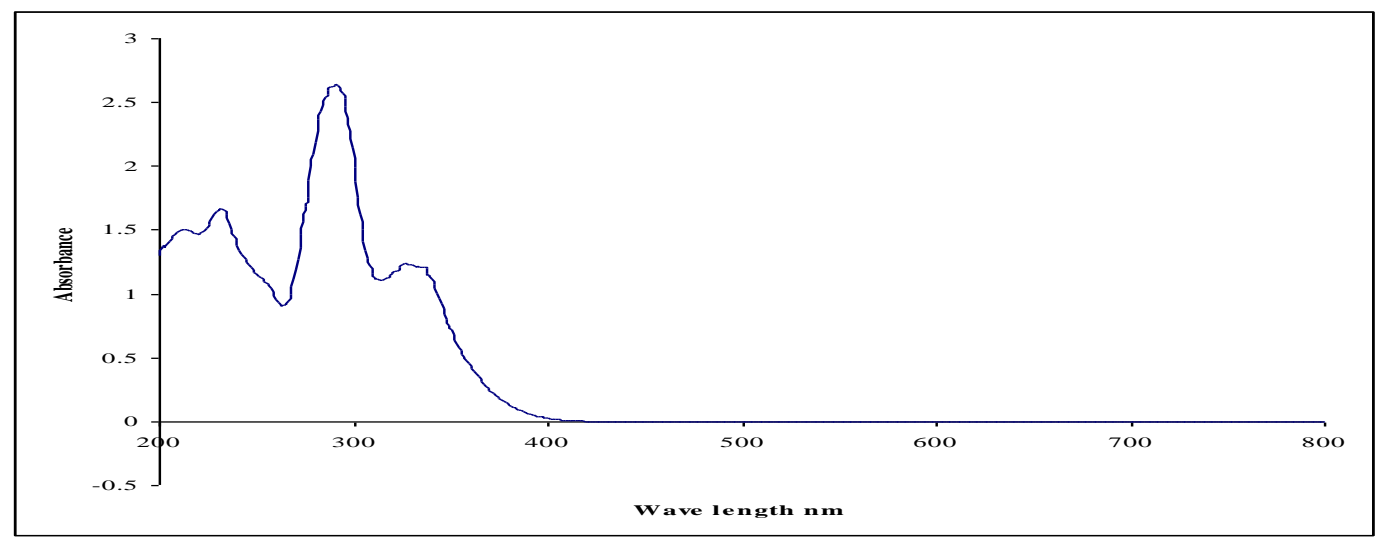

Fig.4. Proposed structural formula of Co(Ii) gatifloxacin complex 


\subsection{Infrared analysis of the metal complexes}

The infrared (IR) spectral scanning of gatifloxacin sesquihydrate, anhydrous gatifloxacin, and the synthetic complexes were conducted for the validation of complexes. The IR spectra of gatifloxacin sesquihydrate were scanned against the reference standard to identify during stability studies. The values of different functional groups in IR spectra of anhydrous gatifloxacin and their metal complexes were reported in Table 4.

\section{TABLE 4}

FTIR absorption data of gatifloxacin and its metal complexes $\left(4000-400 \mathrm{Cm}^{-1}\right)$

\begin{tabular}{|c|c|c|c|c|c|c|c|c|c|c|c|}
\hline $\begin{array}{c}\text { Assignments(c) } \\
\left.\text { m }^{1}\right) \\
\text { GTX and } \\
\text { GTX-Complex }\end{array}$ & $\begin{array}{c}\text { GT } \\
\mathbf{X}\end{array}$ & GTX Co & plex with & & & & & & & & \\
\hline & 340 & $\mathrm{Mg}$ & $\mathrm{Ca}$ & $\mathrm{Al}$ & $\begin{array}{l}\mathrm{Cr} \\
344\end{array}$ & $\begin{array}{l}\mathrm{Mn} \\
342\end{array}$ & $\mathrm{Fe}$ & Co & $\mathrm{Ni}$ & $\mathrm{Cu}$ & $\mathrm{Zn}$ \\
\hline$v(\mathrm{OH})$ intermol & $\begin{array}{l}0 \\
310\end{array}$ & 3415 & 3412 & 3456 & $\begin{array}{l}6 \\
293\end{array}$ & $\begin{array}{l}5 \\
308\end{array}$ & 3451 & 3396 & 3396 & 3409 & 3415 \\
\hline$v(\mathrm{CH})$ arom & $\begin{array}{l}0 \\
284\end{array}$ & 2983 & 3072 & 3025 & $\begin{array}{l}9 \\
285\end{array}$ & $\begin{array}{l}8 \\
284\end{array}$ & 3025 & 2990 & 2999 & 3000 & 2980 \\
\hline$v(\mathrm{CH})$ aliph & $\begin{array}{l}3 \\
237\end{array}$ & 2845 & 2842 & 2842 & $\begin{array}{l}2 \\
249\end{array}$ & $\begin{array}{l}7 \\
249\end{array}$ & 2856 & 2843 & 2842 & 2834 & 2844 \\
\hline$v(\mathrm{NH})$ and $(\mathrm{OH})$ chel & $\begin{array}{l}5 \\
163\end{array}$ & 2491 & 2480 & 2361 & $\begin{array}{l}1 \\
161\end{array}$ & $\begin{array}{l}1 \\
161\end{array}$ & 2480 & 2480 & 2480 & 2470 & 2491 \\
\hline$v(\mathrm{COO}-)$ as & $\begin{array}{l}8 \\
139\end{array}$ & 1619 & 1616 & 1618 & $\begin{array}{l}8 \\
139\end{array}$ & $\begin{array}{l}5 \\
139\end{array}$ & 1623 & 1608 & 1621 & 1619 & 1620 \\
\hline $\begin{array}{l}v(\mathrm{COO}-) \text { sym } \\
\Delta v=(\mathrm{COO}-) \text { as- } \mathrm{v}(\mathrm{COO}-\end{array}$ & 8 & 1407 & 1400 & 1404 & 8 & 9 & 1396 & 1399 & 1369 & 1374 & 1398 \\
\hline )sym & $\begin{array}{l}240 \\
144\end{array}$ & 212 & 216 & 214 & $\begin{array}{l}220 \\
144\end{array}$ & $\begin{array}{l}214 \\
144\end{array}$ & 227 & 209 & 252 & 245 & 222 \\
\hline$v(\mathrm{C}=\mathrm{C}$ and $\mathrm{C}-\mathrm{N})$ & 8 & 1460 & 1451 & $\begin{array}{l}1458 \\
1569\end{array}$ & 8 & 9 & 1442 & $\begin{array}{l}1448 \\
1571\end{array}$ & $\begin{array}{l}1459 \\
1577\end{array}$ & $\begin{array}{l}1448 \\
1562\end{array}$ & $\begin{array}{l}1448 \\
1574\end{array}$ \\
\hline$v(\mathrm{COOM})$ & 136 & $\begin{array}{l}1582 \\
1530\end{array}$ & 1580 & 1524 & $\begin{array}{l}151 \\
5 \\
137\end{array}$ & $\begin{array}{l}157 \\
0 \\
136\end{array}$ & 1515 & 1523 & 1520 & 1515 & 1531 \\
\hline$v(\mathrm{C}-\mathrm{N})$ & $\begin{array}{l}6 \\
107\end{array}$ & 1370 & 1370 & 1357 & $\begin{array}{l}5 \\
106\end{array}$ & $\begin{array}{l}7 \\
106\end{array}$ & 1364 & 1367 & 1371 & 1376 & 1370 \\
\hline$v(\mathrm{C}-\mathrm{F}, \mathrm{C}-\mathrm{O})$ & 2 & $\begin{array}{l}1072 \\
651,551,5\end{array}$ & $\begin{array}{l}1060 \\
650,549,5\end{array}$ & 1055 & 7 & 0 & $\begin{array}{l}1060 \\
658,55\end{array}$ & $\begin{array}{l}1060 \\
651\end{array}$ & $\begin{array}{l}1061 \\
550\end{array}$ & 1055 & 1061 \\
\hline$v(\mathrm{M}-\mathrm{O})$ & & 19 & 19 & 651 & 532 & 654 & 8 & 550 & 495 & 657 & 653 \\
\hline
\end{tabular}

The IR spectra of gatifloxacin metal complexes were compared with that of anhydrous gatifloxacin for the determination of the coordination sites involved in complex formation. The valence vibration of the carboxylic stretch $\mathrm{m}(\mathrm{C}=\mathrm{O}) \mathrm{c}$ was found at $1726 \mathrm{~cm}^{-1}$ and the pyridone stretch $\mathrm{m}(\mathrm{C}=\mathrm{O}) \mathrm{p}$ at $1618 \mathrm{~cm}^{-1}$. The IR spectrum of gatifloxacin sesquihydrate does not show a well-defined carboxylic stretch, which is consistent with the deprotonation of the carboxylic acid. The molecule exists in bipolar zwitterionic form. Ionic carboxylates show no carbonyl stretch of approximately $1700 \mathrm{~cm}^{-1}$, but the two bands in the range from 1650 to $1510 \mathrm{~cm}^{-1}$ and from 1460 to $1400 \mathrm{~cm}^{-1}$, could be assigned to (O-C-O) asymmetric and symmetric stretching vibrations. In the spectrum of gatifloxacin sesquihydrate the $(\mathrm{O}-\mathrm{C}-\mathrm{O}) \mathrm{a}+(\mathrm{C}=\mathrm{O}) \mathrm{p}$ band appears at $1600-1658 \mathrm{~cm}^{-1}$ with a maximum at $1638 \mathrm{~cm}^{-1},(\mathrm{O}-\mathrm{C}-\mathrm{O}) \mathrm{s}$ band stretch is at $1398 \mathrm{~cm}^{-1}$ and $\mathrm{C}-\mathrm{O}$ absorbs at $1282 \mathrm{~cm}^{-1}$. It was found that on complexation, the characteristic peak of $(\mathrm{C}=\mathrm{O}) \mathrm{p}+(\mathrm{C}-\mathrm{O}-\mathrm{C}) \mathrm{a}$ in spectra of all-metal complexes shifted 
towards lower frequency region i-e in the range $1608-1623 \mathrm{~cm}^{-1}$, and the symmetric vibrations occur in the region of 1407$1370 \mathrm{~cm}^{-1}$ (Ambrose, \& Grasela 1999; Grasela, 2000; Patrick, 2013). These complexes show strong intensity absorption in the region of $1540-1500 \mathrm{~cm}^{-1}$ and weak bands in the region of $651-532 \mathrm{~cm}^{-1}$ and $450-400 \mathrm{~cm}^{-1}$, which are absent in the spectrum of gatifloxacin. All gatifloxacin metal complexes show a broad band between 3590 and $3147 \mathrm{~cm}^{-1}$ with a maximum around $3410 \mathrm{~cm}^{-1}$, corresponding to vibrations $\mathrm{m}(\mathrm{O}-\mathrm{H})$ as well as vibration $\mathrm{N}-\mathrm{H}$ piperazinyl fraction (Grasela, 2000). The latter signal appears in the region of $2491-2344 \mathrm{~cm}^{-1}$ in the IR spectra of the complexes. It indicates that the carboxyl group is deprotonated and the bipolar molecule exists with hydrogen atoms bonded to N-3 to form bonds with hydrogen donors water molecules.

The biological activity of the gatifloxacin and its metal complexes was assayed against the adversity of bacterial strains such as Clostridium perfringens Campylobacter jejuni, Corynebacterium diphtherare, Escherichia coli, Staphylococcus aureus, Salmonella typhi, Pseudomonas aeruginosa, Pasteurella multocida, and Neisseria gonorrhoeae. The antifungal screening involved two fungus species Aspergillus nigerand Fusarium oxysporum. The results of the antibacterial study of the synthesized compounds are shown in Table 1. The results were expressed as excellent activity (150-200\% inhibition), good activity (90-100\% inhibition), moderate activity (75-85\% inhibition), significant activity (50-60\% inhibition), negligible activity (20-30\%inhibition) and no activity.

GTX-Al exhibits good activity whereas all metal complexes show excellent activity against $C$. perfringens. GTX-Mg, GTX-Co, GTX-Zn show good activity while GTX-Fe, GTX-Ni, and GTX-Cu show excellent activity, and GTX-Ca, GTX$\mathrm{Al}$, GTX-Cr, GTX-Mn has moderate activity against $C$. jejuni. GTX-Al has moderate activity and the remaining complexes show excellent activity against $C$. diptherire. Diverse activity against Gram-negative organisms was observed. GTX-Ca and GTX-Mn show excellent activity while GTX-Al exhibits moderate activity. The remaining complexes reflect activity, similar to the gatifloxacin against E.coli. The result GTX-Mg, GTX-Ni, and GTX-Zn show surprisingly excellent activity against $S$. aureus (methicillin-resistant) while GTX-Al has moderate activity and the remaining complexes show activity that is similar to gatifloxacin. Against $S$. typhi GTX-Ca, GTX-Al, GTX-Mn, GTX-Ni, and GTX-Cu exhibits moderate activity while GTX-Mg and GTX-Fe show excellent activity, and GTX-Cr, GTX-Co, GTX-Zn show similar activity to gatifloxacin. GTX-Ca, GTX-Mn, and GTX-Co show excellent antibacterial activity whereas GTX-Al, GTX-Cr, and GTX$\mathrm{Cu}$ show moderate and other complexes show similar activity to gatifloxacin against $P$. aeruginosa. Except for GTX-Ca and GTX-Al, all complexes have excellent intrinsic activity against bacterium P. multocida. GTX-Mg shows excellent activity whereas the rest of the complexes exhibit similar activity to that of gatifloxacin against $N$. gonorrhoeae. The enhanced intrinsic activity of complexes can be explained based on cell permeability. The lipid membrane around the cell favors the penetration of lipid-soluble materials. Liposolubility is a key factor that controls antimicrobial activity. Increased liposolbility of the ligand upon metal chelation may contribute to its facilitated transport into the bacterial cell, which blocks the metal-binding sites in the enzymes of microorganisms (Tümer et al., 1999; Imran et al., 2007; Sultana et al., 2013; Jain et al., 2002).

\section{Conclusion}

Antimicrobial analysis of the complexes and ligand were evaluated among different bacterial strains such as Clostridium perfringens (C.perfringens), Campylobacter jejuni (C.jejuni), Corynebacterium diphtheria (C.diphtheriae), Escherichia coli (E.coli), Staphylococcus aureus (S.aureus), Salmonella typhi (S.typhi), Pseudomonas aeruginosa (P.aeruginosa), Pasteurella multocida (P.multocida), Neisseria gonorrhoeae (N.gonorrhoeae) and fungal strains were studied against two species fungus Aspergillus niger (A.niger) and Fusarium oxysporum (F.oxysporum). The present study concluded that gatifloxacin and metal complexes can be used as a good drug of choice to manage bacterial diseases after evaluating the invitro studies. The antibacterial activity of the metal complexes of gatifloxacin was found to highly active as compared to gatifloxacin itself. It was also observed that $\mathrm{pH}$ affected the antibacterial activity of metal complexes.

\section{Conflict of interest}

It is declared that there is no conflict of interest in between Authors 


\section{Acknowledgment}

The Authors are grateful to Dean faculty of Science for provide funds to execute this project.

\section{References}

1. Al-Abdullah, E. S. (2012). Gatifloxacin. In Profiles of Drug Substances, Excipients and Related Methodology (Vol. 37, pp. 183-243). Academic Press.

2. Repchinsky, C. (2003). CPS 2003. Canadian Pharmacists Association. Ottawa, Ontario.

3. Blum, M. D., Graham, D. J., \& McCloskey, C. A. (1994). Temafloxacin syndrome: review of 95 cases. Clinical Infectious Diseases, 18(6), 946-950.

4. Lipsky, B. A., \& Baker, C. A. (1999). Fluoroquinolone toxicity profiles: a review focusing on newer agents. Clinical Infectious Diseases, 28(2), 352-361.

5. Zhao, X., Xu, C., Domagala, J., \& Drlica, K. (1997). DNA topoisomerase targets of the fluoroquinolones: a strategy for avoiding bacterial resistance. Proceedings of the National Academy of Sciences, 94(25), 13991-13996.

6. Domagala, J. M. (1994). Structure-activity and structure-side-effect relationships for the quinolone antibacterials. Journal of Antimicrobial Chemotherapy, 33(4), 685-706.

7. Park-Wyllie, L. Y., Juurlink, D. N., Kopp, A., Shah, B. R., Stukel, T. A., Stumpo, C., ... \& Mamdani, M. M. (2006). Outpatient gatifloxacin therapy and dysglycemia in older adults. New England Journal of Medicine, 354(13), 13521361.

8. Drlica, K. (1999). Features-Refining the Fluoroquinolones-Basic efforts to understand quinolone biology may prolong the health value of these widely used antibacterial agents. ASM News-American Society for Microbiology, 65(6), 410-415.

9. Fukuda, H., Kishii, R., Takei, M., \& Hosaka, M. (2001). Contributions of the 8-methoxy group of gatifloxacin to resistance selectivity, target preference, and antibacterial activity against Streptococcus pneumoniae. Antimicrobial agents and chemotherapy, 45(6), 1649-1653.

10. Ito, T., Matsumoto, M., \& Nishino, T. (1995). Improved bactericidal activity of Q-35 against quinolone-resistant staphylococci. Antimicrobial agents and chemotherapy, 39(7), 1522-1525.

11. Fukuda, H., \& Hiramatsu, K. (1999). Primary Targets of Fluoroquinolones in Streptococcus pneumoniae. Antimicrobial Agents and Chemotherapy, 43(2), 410-412.

12. Farrell, N. (2003). Metal complexes as drugs and chemotherapeutic agents. 809-840.

13. Sabale, P. M., Kaur, P., Patel, Y., Patel, J., \& Patel, R. (2012). Metalloantibiotics in therapy: An overview. J Chem Pharm Res, 4(11), 4921-4936.

14. Sadler, P. J., \& Guo, Z. (1998). Metal complexes in medicine: design and mechanism of action. Pure and Applied Chemistry, 70(4), 863-871.

15. Tarushi, A., Kljun, J., Turel, I., Pantazaki, A. A., Psomas, G., \& Kessissoglou, D. P. (2013). Zinc (II) complexes with the quinolone antibacterial drug flumequine: structure, DNA-and albumin-binding. New Journal of Chemistry, 37(2), 342-355.

16. Perilla, M. J. (2003). Manual for the laboratory identification and antimicrobial susceptibility testing of bacterial pathogens of public health importance in the developing world; Haemophilus influenzae, Neisseria meningitidis, Streptococcus pneumoniae, Neisseria gonorrhoeae, Salmonella serotype Typhi, Shigella, and Vibrio cholerae.

17. FDA, A. P. (2015). Methods Validation for Drugs and Biologics Guidance for Industry, US Department of Health and Human Services Food and Drug Administration. Center for Drug Evaluation and Research, Center for Drug Evaluation and Research (CDER), Center for Biologics Evaluation and Research (CBER).

18. Tümer, M., Köksal, H., Sener, M. K., \& Serin, S. (1999). Antimicrobial activity studies of the binuclear metal complexes derived from tridentate Schiff base ligands. Transition Metal Chemistry, 24(4), 414-420.

19. Imran, M., Iqbal, J., Iqbal, S., \& Ijaz, N. (2007). In vitro antibacterial studies of ciprofloxacin-imines and their complexes with $\mathrm{Cu}$ (II), Ni (II), Co (II), and Zn (II). Turkish journal of biology, 31(2), 67-72.

20. Sultana, N., Arayne, M. S., Rizvi, S. B. S., Haroon, U., \& Mesaik, M. A. (2013). Synthesis, spectroscopic, and biological evaluation of some levofloxacin metal complexes. Medicinal Chemistry Research, 22(3), 1371-1377.

21. Jain, S., Jain, N. K., \& Pitre, K. S. (2002). Bio-inorganic studies on the Fe (II) sparfloxacin complex. Metal-Based Drugs, 9(1-2), 1-8.

22. Saravolatz, L. D., \& Leggett, J. (2003). Gatifloxacin, gemifloxacin, and moxifloxacin: the role of 3 newer fluoroquinolones. Clinical infectious diseases, 37(9), 1210-1215. 
Ahmed et al., 2021

23. Grasela, D. M. (2000). Clinical pharmacology of gatifloxacin, a new fluoroquinolone. Clinical infectious diseases, 31(Supplement_2), S51-S58.

24. Ambrose, P. G., \& Grasela, D. M. (1999, September). Effect of pharmacokinetic and microbiological variability on the pharmacodynamics of gatifloxacin and levofloxacin against Streptococcus pneumoniae. In 39th Interscience Conference on Antimicrobial Agents and Chemotherapy.

25. Patrick, G. L. (2013). An introduction to medicinal chemistry. Oxford university press.

Received: $17^{\text {th }}$ August, 2020

Accepted: $21^{\text {th }}$ November, 2020 